\title{
Economic Geography and Economic Voting: Evidence from the US States
}

\author{
MICHAEL EBEID AND JONATHAN RODDEN*
}

\begin{abstract}
If voters use information about the economy to assess the competence of incumbents, a connection between economic conditions and incumbent success should only be discernible in settings where public policy might plausibly affect the economy, and where the assignment of government responsibility is relatively straightforward. Applying this logic to gubernatorial elections in the United States, we test the following hypothesis: the connection between economic conditions and incumbents' vote shares is mediated by the structure of the state economy. This hypothesis is premised on the idea that voters understand that raw macroeconomic aggregates - when driven by factors like weather, commodity prices and federal policy - are poor signals of incumbent performance. Using data from gubernatorial elections held between 1950 and 1998 , we show that the connection between macroeconomic indicators and incumbent success is weak in states dominated by natural resources and farming but quite strong elsewhere. This finding helps explain why earlier studies found no connection between state-level economic conditions and gubernatorial elections.
\end{abstract}

Most politicians and pundits take it for granted that the state of the economy plays a decisive role in electoral outcomes. Invariably, they see a strong economy as a boon for an incumbent's re-election hopes and a weak economy as a curse on them. These beliefs draw support from numerous studies that demonstrate a connection between national macroeconomic conditions in the United States and aggregate national election results. ${ }^{1}$ However, researchers have been less successful in efforts to detect an analogous relationship between state-level economic conditions and state-level elections. In particular, several analyses of gubernatorial elections find that gubernatorial vote shares are essentially impervious to fluctuations in state economic conditions. ${ }^{2}$ This finding seems especially perplexing in an era when most governors devote tremendous resources to the economic well-being and development of their states. Why would governors focus so much attention on economics if not for the electoral rewards such attention presumably bestows?

In trying to resolve this empirical puzzle, we also address a general theoretical question. In what situations do economic conditions affect election outcomes? While aggregate

* Department of Political Science, Boston University; and Department of Political Science, Massachusetts Institute of Technology, respectively. The authors wish to thank Christopher Anderson and Daniel Dowd for useful comments and discussions.

${ }^{1}$ For example, Gerald H. Kramer, 'Short-Term Fluctuations in U.S. Voting Behavior', American Political Science Review, 65 (1971), 131-43; Ray Fair, 'The Effect of Economic Events on Votes for President', Review of Economics and Statistics, 60 (1978), 159-72; Edward Tufte, Political Control of the Economy (Princeton, N.J.: Princeton University Press, 1978); Steve J. Rosenstone, Forecasting Presidential Elections (New Haven, Conn.: Yale University Press, 1983); Douglas A. Hibbs, The American Political Economy (Cambridge, Mass.: Harvard University Press, 1987); Robert S. Erikson, 'Economic Conditions and the Presidential Vote', American Political Science Review, 83 (1989), 567-73; Thomas M. Holbrook, 'Presidential Elections in Space and Time', American Journal of Political Science, 35 (1991), 91-109.

2 Patrick J. Kenney, 'The Effects of State Economic Conditions on the Vote for Governor', Social Science Quarterly, 64 (1983), 154-62; Samuel Peltzman, 'Economic Conditions and Gubernatorial Elections', AEA Papers and Proceedings, 7 (1987), 293-7; John E. Chubb, 'Institutions, the Economy, and the Dynamics of State Elections', American Political Science Review, 82 (1988), 133-54. 
evidence of economic voting at the national level in the United States is strong, the cross-national empirical literature is mixed. A recent review concludes that in different samples different economic variables sometimes matter for political outcomes, but the findings are far from robust. ${ }^{3}$ This should not be surprising, given that voters possess different information and incentives in different political systems. For instance, Powell and Whitten demonstrate that the effect of economic performance on voting is weak in countries in which 'policymaking responsibility is blurred between government and opposition', and quite strong in countries where 'responsibility is more sharply focused'. 4 Following a similar logic, other studies suggest that economic voting is stronger during periods of unified party control of government than under divided government. ${ }^{5}$

Voters might consider a wide range of information when making assessments about incumbents and challengers. Whether they see and feel it directly or rely on media reports, voters seem to use information about the economy to assess the performance of incumbent politicians. However, such information is likely to be useful only if voters can reasonably attribute economic outcomes to the actions of incumbent individuals or parties. ${ }^{6}$ The studies cited above suggest that it is difficult for voters to establish a causal link between actions and outcomes under coalition or divided government. More generally, these results suggest that if voters are rational (or even quasi-rational) and reasonably discerning, economic voting should not be a universal phenomenon. Rather, we should expect to see evidence of a relationship between economic data and electoral results primarily in places and at times where signals can be distinguished from noise - that is, where economic information is relatively easy to interpret and can be plausibly connected with incumbent performance.

This article uses evidence from the US states to take this argument in a new direction. Specifically, we consider the challenges voters in multi-tiered systems of government face in attempting to apportion policy-making responsibility for economic conditions. We argue that even if all subnational governments in a multi-tiered system have identically extensive fiscal and regulatory tools at their disposal, the usefulness of local economic information for voters might vary a great deal from one state to another depending on the character of the subnational economy. Apportioning responsibility for local economic conditions to subnational officials in multi-tiered systems is quite difficult in general, but the possibility of doing so is heavily conditioned by economic geography.

\footnotetext{
3 José Antonio Cheibub and Adam Przeworski, 'Democracy, Elections, and Accountability for Economic Outcomes', in Adam Przeworski, Susan Stokes and Bernard Manin, eds, Democracy, Accountability, and Representation (Cambridge: Cambridge University Press, 1999), p. 230.

${ }^{4}$ G. Bingham Powell Jr and Guy D. Whitten, 'A Cross-National Analysis of Economic Voting: Taking Account of the Political Context', American Journal of Political Science, 37 (1993), 391-414, p. 410; Christopher Anderson, 'Economic Voting and Political Context: A Comparative Perspective', Electoral Studies, 19 (2000), 151-71, provides a review of similar findings, along with further evidence of the relationship between 'clarity of responsibility' and economic voting.

5 Kevin M. Leyden and Stephen A. Borrelli, 'The Effect of State Economic Conditions on Gubernatorial Elections: Does Unified Government Make A Difference?' Political Research Quarterly, 48 (1995), 275-90; Michael Lewis-Beck and Richard Nadeau, 'French Electoral Institutions and the Economic Vote', Electoral Studies, 19 (2000), 171-3.

${ }^{6}$ Business cycles can make the processing of such information more complicated, but voters might deal with this by simply expecting greater economic growth during good times and slower growth during bad times. Bernard Manin, Adam Przeworski and Susan Stokes, 'Elections and Representation', in Przeworski, Stokes, and Manin, eds, Democracy, Accountability, and Representation.
} 
The simple hypothesis explored in this article is that subnational economic voting is more likely to arise in jurisdictions with modern, diversified economies than in those with agricultural or extractive economies. The economic well-being of the population in the former may be closely linked to the presence of mobile investment capital, a good investment environment and a skilled workforce - factors over which state governments may have some influence - while in the latter it is likely to be driven by the value of fixed assets and natural resources. In diversified modern jurisdictions, aggregate information on income growth or unemployment might serve as sensible performance indicators, given the role local politicians can play in making their jurisdictions attractive places for capital and workers. In the latter, however, such indicators may appear less relevant because the jurisdiction's economic fortunes are largely determined by factors obviously beyond the control of local politicians, such as price fluctuations in international commodity markets, the weather and federal subsidies. We test this hypothesis by introducing industrial structure data to a standard model of incumbent vote share in US state gubernatorial elections.

The next section introduces the problem of information, economic outcomes and voting in multi-tiered systems, and the following section lays out the economic geography argument. We then present a basic model - inspired by previous work on gubernatorial elections - that estimates the electoral effects of economic conditions from 1950 to 1998. The next section adapts the basic model to explore the conditional effect of state economic structure. The final section discusses the results and concludes.

\section{ECONOMICS AND ELECTIONS AT THE SUBNATIONAL LEVEL}

The presence of strong subnational governments introduces some of the same challenges to accountability presented by coalition or divided government. If two levels of government (henceforth 'federal' and 'state') have authority over certain aspects of macroeconomic and economic development policy, or at least attempt to claim credit for fostering economic growth, voters may not know how to interpret information about the regional economy. While it is always difficult to differentiate between favourable cyclical or international circumstances and wise policy choices, the task is even more difficult if two levels of government are simultaneously claiming credit for success or shifting blame for failure. Voters in the states have at least four ways of responding to the credit-claiming attempts of state-level officials:

(1) Evaluate the performance of state officials by considering state-level economic information only (i.e., evaluating state officials independently).

(2) Evaluate the performance of state officials by considering state-level economic information relative to national economic information (i.e., evaluating state officials by whether the state economy is better or worse than the overall national economy).

(3) Use information about the national economy to punish and reward the party of the federal executive at all levels of government.

(4) Eschew the use of economic information to evaluate state officials.

We posit that the strategy employed by voters will be shaped in predictable ways by the nature of the political and economic system. Of course, the idea that voters consider subnational economic conditions in any way (the first two strategies) is only plausible (and 
measurable) in countries where economic outcomes actually vary substantially across regions. For this reason, we might expect local elections in Liechtenstein to follow the third or fourth pattern, while the first two patterns might be present in India, Brazil or the United States.

The usefulness of information about the regional economy might also be affected by the fiscal and policy autonomy of the subnational government sector. Consider a range of subnational sectors around the world. At one end of a continuum one might place the municipal government sector in Norway, where the taxing, spending and regulatory activities of local governments are strictly regulated by the central government. ${ }^{7}$ It would be surprising to find that voters employ either of the first two strategies in Norway. One might place the German Länder (states) in the middle of such a continuum. On the one hand, they have considerable expenditure autonomy and at least some state governments do attempt to claim credit for economic development policies. But on the other hand, they have very little autonomy in setting the tax rate or base, and much of their revenue is dedicated to the implementation of federal legislation. An empirical study shows that voters in the German states employ the third strategy - using national-level economic information to punish and reward the party of the federal chancellor in state elections. ${ }^{8}$

At the opposite end of a 'subnational autonomy' continuum one might place the US states, along with the Canadian provinces and Swiss cantons - arguably the most fiscally and politically autonomous subnational entities in the world. In each case, many of the constituent units predate the federal constitution that subsequently provided strong legal and institutional protections of the units' autonomy. In each case, subnational governments engage in significant autonomous economic development activities, and while they do not control monetary policy, they have wide-ranging control over fiscal and regulatory policy.

In political systems where subnational governments enjoy such economic autonomy, it is reasonable to suppose that voters will make independent assessments of the fiscal performance of the subnational units and view these units as fiscal 'sovereigns'. In other words, the first two voter-response strategies discussed above, both of which involve assessment of local-level officials through the use of local economic information, seem to make sense in highly autonomous federated states. Yet for many years the accepted scholarly wisdom in the United States has suggested otherwise. Several studies of aggregate gubernatorial election results from the 1940s to the early 1980s find strong support for the notion that national economic conditions affect gubernatorial candidates' electoral fortunes, but little evidence of an effect from state-level economic conditions. ${ }^{9}$ Moreover, the national effect is directly tied to the president: gubernatorial candidates of the president's political party benefit when the national economy is strong and suffer when it is weak (gubernatorial candidates of the party opposite the president's experience the

\footnotetext{
7 Jørn Rattsø, 'Vertical Fiscal Imbalance and Fiscal Behavior in a Welfare State: Norway', in Jonathan Rodden, Gunnar Eskeland and Jennie Litvack, eds, Decentralization and the Challenge of Hard Constraints (Cambridge, Mass.: MIT Press, 2003).

${ }^{8}$ Susanne Lohmann, David Brady and Douglas Rivers, 'Party Identification, Retrospective Voting, and Moderating Elections in a Federal System: West Germany, 1961-1989', Comparative Political Studies, 30 (1997), 420-49. German voters also have incentives to view Land elections through a federal lens because Land elections determine the make-up of the upper house of parliament.

${ }^{9}$ Kenney, 'The Effects of State Economic Conditions on the Vote for Governor'; Peltzman, 'Economic Conditions and Gubernatorial Elections'; Chubb, 'Institutions, the Economy, and the Dynamics of State Elections'.
} 
reverse). ${ }^{10}$ In terms of the voting strategies outlined above, these studies find little evidence for Strategies 1 or 2, while - as in the German states - they report strong support for Strategy 3.

The standard post-analysis explanation for these findings is that the state of the economy is a national matter that is the responsibility of national officials. According to Peltzman, for instance, the lack of a gubernatorial electoral effect from state economic conditions indicates that voters act 'as if they understand that national rather than local politics have the dominant effect on their income'. ${ }^{11}$ In other words, these previous studies interpret the economic-electoral connection at subnational levels as the product of a relatively sophisticated electorate that sees the economy as a national issue but treats subnational politicians as representatives of the national parties that direct it.

We find these results and this conclusion surprising. Given the autonomy and strength of the US states in comparative perspective, it seems likely that voters do indeed face incentives to use state-level economic information to evaluate the performance of state officials. In order to distinguish local performance from nation-wide shocks and trends or the effects of federal policy, Strategy 2 seems especially attractive for voters in the US states. State governors preside over large, sophisticated bureaucracies that they use in attempts to lure mobile domestic and international investment capital to their states. Many of the states are very active in courting international investors, and have opened permanent offices abroad. Attempts to claim credit for the concomitant job and economic growth seem to dominate state-level electoral politics, ${ }^{12}$ and governors often trumpet the success of their state vis-à-vis others. Governors certainly appear to believe that their electoral fortunes are determined by state-level economic growth, even if the empirical evidence from academic studies has not always supported this conclusion.

The puzzling failure to detect electoral effects from state economic conditions and the unconvincing 'national dominance' explanation of economic factors in subnational elections advanced by Peltzman and others has partly motivated several more recent analyses of the gubernatorial vote. Leyden and Borrelli, using unemployment data as an indicator of economic conditions, argue that state economic conditions impact gubernatorial elections more dramatically when the governor's party also controls the state legislature. ${ }^{13}$ Besley and Case contend that voters' evaluations of state-level tax policy

${ }^{10}$ Using 1982 survey data on individual vote choice, Stein reaches the similar conclusion that voters generally hold the president (and by extension, the president's party) responsible for state economic conditions, and that governors are rewarded or penalized according to their partisan connection to the president; Robert M. Stein, 'Economic Voting for Governor and U.S. Senator: The Electoral Consequences of Federalism', Journal of Politics, 52 (1990), 29-53.

11 Peltzman, 'Economic Conditions and Gubernatorial Elections', p. 296.

12 For instance, Grady reports that in thirty-three of forty-six state-of-the-state addresses delivered in 1988 , governors 'mentioned economic development as one of their top three priorities' (Dennis Grady, 'Managing the State Economy: The Governor's Role in Policymaking', in Eric B. Herzik and Brent W. Brown, eds, Gubernatorial Leadership and State Policy (New York: Greenwood Press, 1990), pp. 105-20, at p. 106). And while this type of credit claiming seems to have grown more prevalent in recent years, by no means is it an entirely new phenomenon. Southern economic historians have shown that aggressive investment promotion has been central to gubernatorial re-election strategies since at least the 1940s (James C. Cobb, The Selling of the South: The Southern Crusade for Industrial Development, 1936-1980 (Baton Rouge: Louisiana State University Press, 1982); Gavin Wright, Old South, New South: Revolutions in the Southern Economy Since the Civil War (Baton Rouge: Louisiana State University Press, 1986)).

${ }^{13}$ Leyden and Borrelli, 'The Effect of State Economic Conditions on Gubernatorial Elections'. 
appear to be made through 'benchmark' comparisons with neighbouring states. ${ }^{14}$ Other studies find evidence that state economic conditions are an important determinant of the individual vote choice. ${ }^{15}$ Viewed as a whole, these and other studies suggest that earlier conclusions that the state economy plays little role in state elections may have been too hasty. ${ }^{16}$ Furthermore, they imply that voters are relatively sophisticated users of economic information, and that the economic-election connection - at least at the subnational level - must be understood in more subtle and qualified terms than previously thought. Our study adds to the scepticism about the findings of initial studies of economics and gubernatorial elections. Specifically, we identify a simple but strikingly important mediating factor that qualifies the connection between state economic conditions and gubernatorial election outcomes - the structure of the state economy.

\section{ECONOMIC STRUCTURE AND ECONOMIC VOTING}

Voters' incentives to use local economic information to assess the performance of incumbents might vary as much within as across countries. The economic geography literature documents a natural pattern of economic development whereby because of transport costs and agglomeration economies, manufacturing and industrialization are concentrated in one or two regions within countries, leaving the rest of the country as a sparsely populated, largely agricultural hinterland. ${ }^{17}$ This phenomenon, when combined with a federal system of government, often means that industrialization is concentrated in a handful of states, while the economy of the median state is dominated by agriculture, natural resource extraction and related services. Prominent examples include the rest of Brazil in relation to the São Paulo region and the Argentine hinterlands vis-à-vis Buenos Aires.

While less extreme, the United States has experienced a pronounced regional pattern of industrialization, first concentrated in the northeastern manufacturing belt and then to a lesser extent along the Pacific Coast, and later spreading to parts of the South and Midwest as transportation costs fell. Perloff et al. estimated that the manufacturing belt - a parallelogram bounded roughly by Green Bay, St Louis, Baltimore and Portland, Maine - accounted for 74 per cent of US manufacturing employment around the turn of the century, a figure that had only decreased to 64 per cent by $1957 .{ }^{18}$ Manufacturing and (non-agricultural) services have spread more evenly throughout the country ever since, and the economies of some states, especially in the Midwest and South, have undergone major transformations.

Using the classifications of the Bureau of Economic Analysis, Figure 1 displays the portion of each state's yearly total earnings that was derived from farming, agricultural

14 Timothy Besley and Ann Case, 'Incumbent Behavior: Vote-Seeking, Tax-Setting, and Yardstick Competition', American Economic Review, 85 (1995), 25-45.

15 Richard G. Niemi, Harold W. Stanley and Ronald J. Vogel, 'State Economies and State Taxes: Do Voters Hold Governors Accountable?' American Journal of Political Science, 39 (1995), 936-57; Lonna Rae Atkeson and Randall W. Partin, 'Economic and Referendum Voting: A Comparison of Gubernatorial and Senatorial Elections', American Political Science Review, 89 (1995), 99-107.

16 See also Robert C. Lowry, James E. Alt and Karen E. Ferree, 'Fiscal Policy Outcomes and Electoral Accountability in American States', American Political Science Review, 92 (1998), 759-74.

17 Paul Krugman, Geography and Trade (Cambridge, Mass.: MIT Press, 1991); Masahisa Fujita, Paul Krugman and Anthony Venables, The Spatial Economy: Cities, Regions, and International Trade (Cambridge, Mass.: MIT Press, 1999).

18 H.E. Perloff, E. Dunn and R. Muth, Regions, Resources, and Economic Growth (Baltimore, Md.: Johns Hopkins University Press, 1960). 


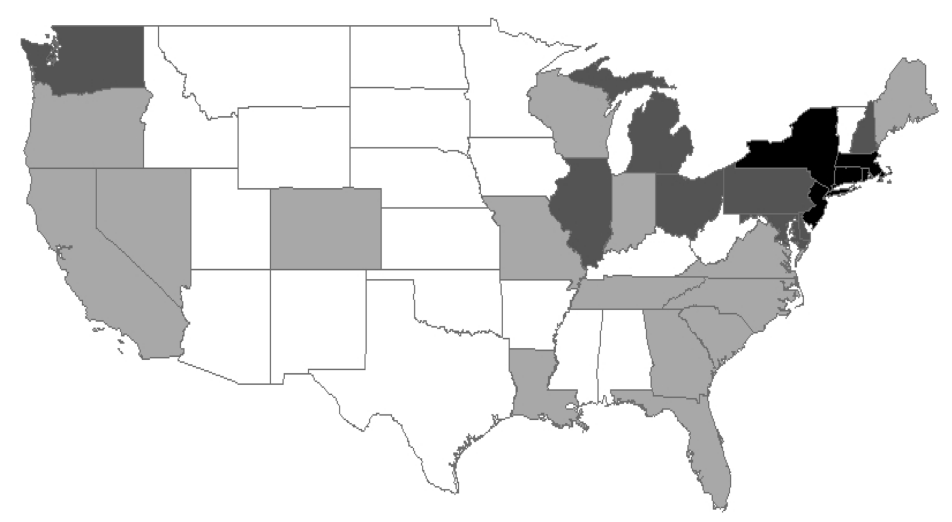

$1940-44$

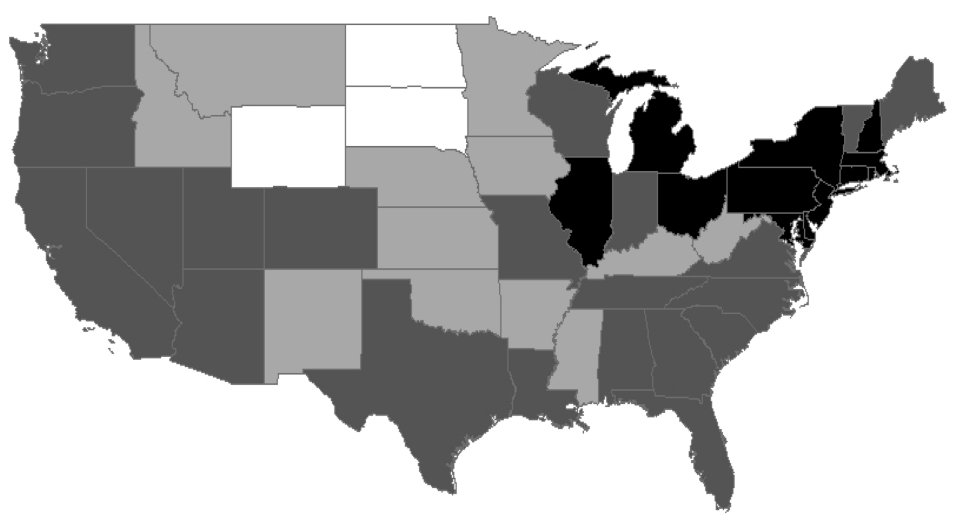

1970-74

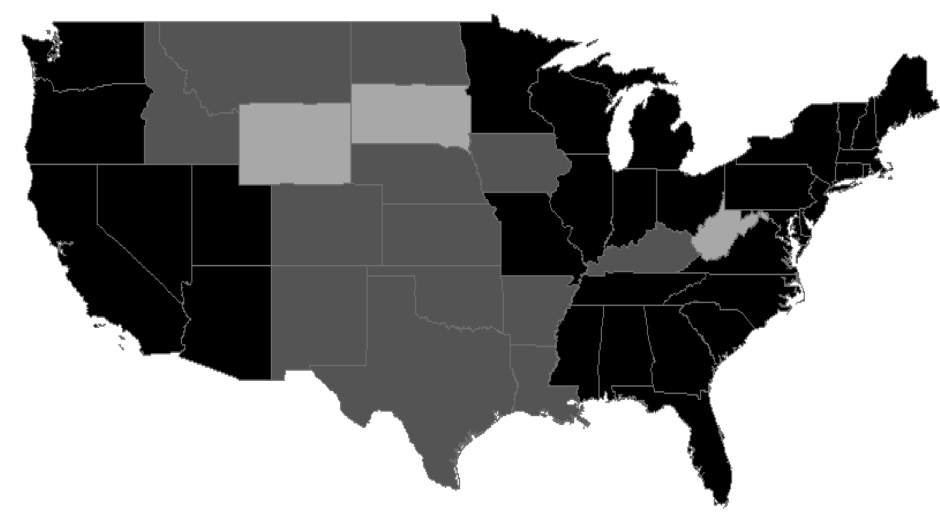

1994-98

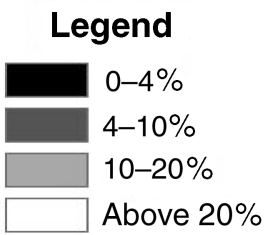

Fig. 1. Average earnings from farming, agricultural services and mining as share of total state earnings, selected years 
services and mining in the 1940s, then again in the1970s and at the end of the century. ${ }^{19}$ Lighter shades indicate greater dependence on the sale of 'primary products'. The difference between the northeastern manufacturing belt and the rest of the country is clearly visible in the 1940s and 1970s maps, but by the end of the century, the sale of primary products represented only a miniscule portion of the state economy in the far west and in every state east of the Mississippi except for West Virginia. Yet even today a large swath of the country has experienced relatively little industrialization, and the economies of several states are still strongly linked to agricultural products and natural resources. In fact, the importance of farming and natural resources to the economy in the middle section of the country is probably underestimated by the index presented in Figure 1, given the exposure of banks and other service industries to fluctuations in income from primary products. In a state like North Dakota or South Dakota, if an entire year's crop is destroyed by disease, drought or flooding, the state's overall growth rate takes a dramatic dive. $^{20}$

Such cross-state and diachronic differences in economic structure have potentially important implications for political accountability at the state level. For example, in the late nineteenth and early twentieth centuries, many farmers in the American periphery realized that their economic prosperity was largely shaped by events and political decisions well beyond the control of state governments. Not only were farmers dependent upon the weather, but they were price-takers in national and international markets, who relied on railroad and other transportation networks that tended to be owned and controlled by out-of-state firms. As such, the most important political issues in the periphery usually required the action of the federal government rather than the states; favourable tariffs and farm prices topped the agenda, along with policies that would rein in the bankers and railroad owners of the eastern capitalist establishment. ${ }^{21}$

In a context like this - where the state economy is largely driven by weather and commodity markets - indicators of state economic conditions such as unemployment, gross state product or personal income would seem to transmit very little information about the performance of state-level officials. We hypothesize that voters in such states are likely to find it difficult to use local economic data to facilitate performance assessments. When agriculture, mining and other primary product exports dominate a state's economy, even a rather poorly informed voter is likely to understand that marginal changes in growth and unemployment rates - even relative to national rates are not easily traced to the performance of the state's governor. Rather, the government policy decisions that most plausibly affect income levels are in the hands of federal officials - tariffs, price supports, subsidies, energy policy and, in some cases, land use. If most productive activity in the state is associated with fixed assets, like agricultural or grazing land, mines or oil reserves, an incumbent governor may expect to be held accountable by voters as much for her ability to attract subsidies or price supports from the federal government as her ability to manage the local economy and create an attractive business environment.

\footnotetext{
19 State-level industry data is compiled by the Bureau of Economic Analysis (http://www.bea.doc.gov). The data we used come from the BEA's Series SA05.

${ }^{20}$ For example, North Dakota's real per capita income fell by 15 per cent in 1980 , a year in which the state suffered a severe drought.

${ }^{21}$ Elizabeth Sanders, Roots of Reform: Farmers, Workers, and the American State 1877-1917 (Chicago: University of Chicago Press, 1999).
} 
In short, while the rationality of conditioning one's vote choice in subnational elections on raw or relative economic aggregates is debatable even in the industrialized core, it is extremely suspect in the dependent, price-taking periphery. This condition would explain why a link between the state economy and the success of gubernatorial incumbents could not be established in previous studies using panels of state elections that assigned each state equal weight regardless of economic structure. If state-level economic voting is contingent on economic geography, the downward bias on the coefficients for statelevel macroeconomic variables would be even more severe in samples dominated by earlier years, when manufacturing was still relatively concentrated in the northeastern belt and a much larger group of states was dominated by agriculture and primary products.

The next section estimates a simple model of gubernatorial incumbent vote share in accordance with existing literature. The following section then interacts macroeconomic indicators with variables capturing the economic structures of states, demonstrating very clearly that the economic-electoral connection is contingent on economic geography.

\section{A SiMPLE MODEL OF ECONOMIC CONDITIONS AND THE GUBERNATORIAL VOTE}

Following previous research, ${ }^{22}$ we have constructed a simple model of the aggregate gubernatorial vote that puts potential economic influences at centre stage. ${ }^{23}$ To estimate this model, we have compiled data on competitive gubernatorial elections ${ }^{24}$ in forty-seven states from 1950 to $1998 .{ }^{25}$ Our dependent variable is the incumbent party's share of the two-party vote. Like other scholars before us, we expect voters to associate economic policies and outcomes not merely with the particular individual in the governor's office, but with his or her party as well. Accordingly, when an incumbent governor does not run for re-election, the governor's party is likely to shoulder responsibility for the governor's

${ }^{22}$ Both our model and the statistical technique we use to estimate it are similar to those used in Peltzman, 'Economic Conditions and Gubernatorial Elections'.

${ }^{23}$ We do not claim to have included in our model every factor that might conceivably impact gubernatorial election outcomes. Among the possible factors that we do not evaluate are campaign spending, gubernatorial job performance ratings and presidential approval ratings. One reason to favour parsimony in model construction is that there remains much scholarly debate about whether - and to what extent - such factors do indeed make a difference in elections. For instance, Carsey and Wright find that presidential approval impacts gubernatorial election outcomes, while Atkeson and Partin do not (Thomas M. Carsey and Gerald C. Wright, 'State and National Factors in Senatorial and Gubernatorial Elections', American Journal of Political Science, 42 (1998), 994-1002; Atkeson and Partin, 'Economic and Referendum Voting'). Practical data constraints also limit thorough consideration of certain factors as comprehensive data on such things as gubernatorial job performance simply are not available for all states in the complete time period covered in our study.

${ }^{24}$ We define an election as 'competitive' if both the major parties received at least 20 per cent of the two-party vote. In practice, this requirement serves to eliminate from the dataset several elections of the mid-century 'solid south' period when Democratic candidates in many southern states routinely won by landslide margins.

${ }^{25}$ We exclude Alaska and Hawaii. Also, the peculiarities of Louisiana's nonpartisan primaries and runoff elections make its electoral results difficult to compare to other states. The voting and incumbency data for 1950 to 1990 come from four ICPSR studies: State-Level Congressional, Gubernatorial and Senatorial Election Data for the United States, 1824-1972 (ICPSR 0075), State-Level Presidential Election Returns, 1824-1972 (ICPSR 0019), General Election Data for the United States, 1950-1990 (ICPSR 0013), and Candidate and Constituency Statistics of Elections in the United States, 1788-1990 (ICPSR 7757). Election and incumbency data for the 1990s were obtained from America Votes. Income data come from the US Department of Commerce's Bureau of Economic Analysis (available online at http://www.bea.doc.gov). Unemployment data are from the US Department of Labor's Bureau of Labor Statistics (available online at http://www.bls.gov for years since 1977, and for earlier years in the Statistical Abstract of the United States). 
performance over the prior term. When an incumbent does run, he typically enjoys well-known advantages that make races with an incumbent notably different from open races. Therefore, we include in the model a dummy variable to indicate the presence of an incumbent candidate.

Because states vary in their general tendencies to support Democratic versus Republican candidates, we also include a variable for the incumbent party's 'normal vote'. A party's normal vote in a state serves as a measure of the partisan predisposition of the state, and indicates the degree of support a party candidate can typically expect to receive in the state. We operationalize the normal vote variable as the average share of the two-party vote received by the incumbent party in the immediately prior gubernatorial, senatorial and presidential elections. The year in which a gubernatorial election occurs relative to the presidential election cycle is also likely to affect candidates' vote shares. Most states currently conduct gubernatorial elections in non-presidential election years. Such races may reflect the much discussed 'midterm punishment' phenomenon whereby candidates from the president's party typically suffer because of voter weariness or displeasure with the president. In contrast, gubernatorial elections held in presidential election years may be affected by 'presidential coattails'. When a party's presidential candidate wins, other candidates on the same party ticket usually benefit. To control for these influences, we have added midterm punishment and presidential coattails variables to our model. ${ }^{26}$

As discussed above, there are a variety of ways voters might use economic information to assess the performance of state officials. We have therefore developed two distinct specifications of the basic model. The first and most simple specification tests the possibility that state economic conditions alone affect incumbent success (Strategy 1), while the second specification tests the possibilities that economic conditions affect gubernatorial elections according to the relative strength of the state economy vis-à-vis the national economy (Strategy 2) and/or that it is the president's management of the national economy that matters (Strategy 3).

Following previous studies, we use two separate measures of national and state economic conditions - one-year growth rates of real per capita income (RPCI) and unemployment. ${ }^{27}$ Reliable data for RPCI are available since the Second World War, while

\footnotetext{
${ }^{26} \mathrm{We}$ are able to estimate the impact of presidential coattails more precisely than the midterm punishment effect. For the midterm punishment effect, we simply include an 'inverse' dummy variable to denote years in which a gubernatorial election occurred during the middle of a president's term (see Table 1 for the precise coding rule). For the coattails effect, we use the percentage of the two-party presidential vote received by the incumbent gubernatorial party's presidential candidate to measure the 'length' of the presidential candidate's coattails: the higher that percentage, the longer we expect the coattails to be-i.e., the more we expect the gubernatorial candidate to benefit from the strength of his party's presidential candidate. However, to assess the coattails effect accurately, we also must include a dummy variable that indicates whether a gubernatorial election was held in a presidential election year. Without this dummy variable we could not distinguish a zero value for the percentage of the two-party presidential vote received by the incumbent gubernatorial party's presidential candidate as meaning 'the incumbent gubernatorial party's presidential candidate received no votes' from meaning 'there was no presidential election that year'. Thus, presidential coattails are measured by the combined effects of the presidential election year dummy variable and the percentage of the two-party presidential vote received by the incumbent gubernatorial party's candidate.

${ }^{27}$ There are a variety of ways to assess economic conditions using real per capita income or unemployment. One might consider, for instance, the absolute level of RPCI (or unemployment), the first difference, or the percentage change over a specified period. Perhaps the most common way - both in the relevant academic literature and the popular press - to operationalize these is with RPCI as a percentage change (one-year growth rate) and unemployment as an absolute level or first difference. However, for the sake of consistency and ease of
} 
state-level unemployment data are only available since $1968 .{ }^{28}$ Given this discrepancy in available data, we have decided not to use both economic indicators in the same model specification but, rather, estimate two versions of each specification: one in which economic conditions are measured by RPCI, and one in which economic conditions are measured by unemployment. Including economic indicators in the first specification is straightforward: a variable for one-year percentage changes in state economic performance (either RPCI or unemployment) enters the model directly. Estimation of the second specification is more complex. To test the proposition that the relative strength of the state economy affects election outcomes, we use the difference between the state growth rate and the national growth rate (either RPCI or unemployment). Again, the reasoning here is that voters may be inclined to evaluate governors not simply on the raw state growth rate (Strategy 1 and the first specification), but instead on whether the governor brings about better or worse economic conditions than are present at the national level. To test the proposition that the president's management of the national economy affects election outcomes requires an interaction specification of the effects of the national economy. Accordingly, the national growth rate enters the model directly (to test for possible direct national economic effects on the gubernatorial vote), and interacted with a dummy variable that indicates whether the incumbent gubernatorial party is the same as the sitting president's party. A positive coefficient on the interaction term in the RPCI specifications, or a negative coefficient in the unemployment specifications, suggests that the electorate does indeed hold representatives of the president's party responsible for the president's management of the national economy.

To estimate these models, we use the fixed effects technique (least squares dummy variables), which is a common approach for analysis of panel data (i.e., cross-sectionally dominant pooled data). With this approach, the regression equation includes not only the substantive variables already described but also a set of dummy variables to represent each cross-sectional unit (i.e., the states). These dummy variables control for unit effects that can contaminate the error term by moving the unit effects from the error term into the coefficients for the dummy variables. The actual estimates of the unit effects are of little theoretical interest, so we do not report them. Table 1 summarizes all of the variables used in the analysis. Full equations for the specifications are as follows:

\section{Specification 1 (Absolute State Conditions), Version A (RPCI) \\ Incumbent Vote $=\alpha+\beta_{1}$ Normal Vote $+\beta_{2}$ Incumbent Candidate \\ $+\beta_{3}$ Presidential Vote $+\beta_{4}$ Presidential Election \\ $+\beta_{5}$ Midterm Punish $+\beta_{6}$ State Economy_RPCI \\ + [state dummy variables] $+\varepsilon$}

(F'note continued)
interpretation, we report results using a percentage change operationalization (i.e., one-year growth rates) for both
RPCI and unemployment. Note that we also estimated our models using levels and first differences and obtained
similar results. Furthermore, we explored other economic indicators, such as the growth of real gross state product
per capita, which is available since 1977 . We do not report these results, which are very similar to the results
reported below for real per capita income, because of the shorter time series and the fact that real gross state product
per capita and real per capita income are correlated at above 0.9 .
28 In the 1970 s, the Bureau of Labor Studies changed the technique it uses to measure unemployment. Due to
concerns about the comparability of unemployment rates before and after this change, we also estimated our model
using only post-1977 data. The results, which are available upon request, are very similar to those reported below. 
TABLE 1 Description of Variables

\begin{tabular}{|c|c|}
\hline Variable & Description \\
\hline Incumbent Vote & $\begin{array}{l}\text { The incumbent gubernatorial party's percentage } \\
\text { share of the two-party vote }\end{array}$ \\
\hline Normal Vote & $\begin{array}{l}\text { The average share of the two-party vote received } \\
\text { by the incumbent party in the immediately prior } \\
\text { gubernatorial, senatorial and presidential } \\
\text { elections }\end{array}$ \\
\hline Incumbent Candidate & $\begin{array}{l}1 \text {, if the incumbent party fields an incumbent } \\
\text { candidate; } 0 \text { otherwise }\end{array}$ \\
\hline Presidential Vote & $\begin{array}{l}\text { Share of the two-party vote received by the } \\
\text { incumbent gubernatorial candidate's party in } \\
\text { concurrent presidential election ( } 0 \text { if no } \\
\text { presidential election) }\end{array}$ \\
\hline Presidential Election & $\begin{array}{l}1 \text {, in presidential election years; } 0 \text {, in } \\
\text { non-presidential election years }\end{array}$ \\
\hline Midterm Punish & $\begin{array}{l}\text { 1, in non-presidential election years when the } \\
\text { incumbent party candidate shares party affiliation } \\
\text { with the sitting president; }-1 \text {, in } \\
\text { non-presidential election years when the } \\
\text { incumbent party candidate does not share party } \\
\text { affiliation with the sitting president; } 0 \text {, in } \\
\text { presidential election years }\end{array}$ \\
\hline Same Party & $\begin{array}{l}1 \text {, if the incumbent gubernatorial party is the } \\
\text { same as the president's party; }-1 \text {, if different }\end{array}$ \\
\hline National Economy_RPCI & $\begin{array}{l}\text { One-year percentage growth in national real per } \\
\text { capita income* }\end{array}$ \\
\hline State Economy_RPCI & $\begin{array}{l}\text { One-year percentage growth in state real per } \\
\text { capita income* }\end{array}$ \\
\hline Relative State Economy_RPCI & $\begin{array}{l}\text { One-year percentage growth in state real per } \\
\text { capita income minus the one-year percentage } \\
\text { growth in national real per capita income* }\end{array}$ \\
\hline National Economy_UNEMP & $\begin{array}{l}\text { One-year percentage increase in the national } \\
\text { unemployment rate* }\end{array}$ \\
\hline State Economy_UNEMP & $\begin{array}{l}\text { One-year percentage increase in the state } \\
\text { unemployment rate* }\end{array}$ \\
\hline Relative State Economy_UNEMP & $\begin{array}{l}\text { One-year percentage increase in the state } \\
\text { unemployment rate minus the one-year } \\
\text { percentage increase in the national } \\
\text { unemployment rate* }\end{array}$ \\
\hline Primary Product Index & $\begin{array}{l}\text { The proportion of the state's yearly total industry } \\
\text { earnings derived from farming, agricultural } \\
\text { services and mining (five-year moving average) }\end{array}$ \\
\hline [state dummy variables] & $\begin{array}{l}1 \text {, when the Republicans are the incumbent } \\
\text { gubernatorial party in the state; }-1 \text {, when the } \\
\text { Democrats are the incumbent gubernatorial party } \\
\text { in the state }\end{array}$ \\
\hline
\end{tabular}

*The one-year increase period for all economic variables is the election year relative to the previous year. For example, National Economy_RPCI for the election year 1992 measures the percentage growth in national real per capita income experienced between 1991 and 1992. 
Specification 2 (Relative State Conditions), Version A (RPCI)

Incumbent Vote $=\alpha+\beta_{1}$ Normal Vote $+\beta_{2}$ Incumbent Candidate

$+\beta_{3}$ Presidential Vote $+\beta_{4}$ Presidential Election

$+\beta_{5}$ Midterm Punish $+\beta_{6}$ National Economy_RPCI

$+\beta_{7}$ (National Economy_RPCI $\times$ Same Party)

$+\beta_{8}$ Relative State Economy_RPCI + [state dummy variables] $+\varepsilon$

Specification 1 (Absolute State Conditions), Version B (Unemployment)

Incumbent Vote $=\alpha+\beta_{1}$ Normal Vote $+\beta_{2}$ Incumbent Candidate

$+\beta_{3}$ Presidential Vote $+\beta_{4}$ Presidential Election

$+\beta_{5}$ Midterm Punish $+\beta_{6}$ State Economy_UNEMP

+ [state dummy variables] $+\varepsilon$

Specification 2 (Relative State Conditions), Version B (Unemployment)

Incumbent Vote $=\alpha+\beta_{1}$ Normal Vote $+\beta_{2}$ Incumbent Candidate

$+\beta_{3}$ Presidential Vote $+\beta_{4}$ Presidential Election

$+\beta_{5}$ Midterm Punish $+\beta_{6}$ National Economy_UNEMP

$+\beta_{7}$ (National Economy_UNEMP $\times$ Same Party)

$+\beta_{8}$ Relative State Economy_UNEMP + [state dummy variables] $+\varepsilon$

The results for these specifications of the basic model are reported in Table 2. As indicated by the $R^{2}$ values ranging from 0.31 to 0.39 , each specification has a respectable overall fit - a fit similar to previous economic models of the gubernatorial vote. Moreover, in each specification the non-economic variables mostly perform as expected. A party's normal vote gives potential gubernatorial candidates an idea of how they may fare: the higher an incumbent party's normal vote in a state, the greater the percentage of the two-party vote an incumbent party candidate can expect to receive. ${ }^{29}$ Also unsurprising is the substantial incumbency advantage sitting governors enjoy. A governor who runs for re-election typically gets a boost of at least 6 percentage points of the vote. In addition, the timing of a state's gubernatorial election relative to the presidential election cycle proves important. When an election is held in a non-presidential year, candidates who share the president's party affiliation will typically suffer a midterm punishment of between 2 and 3 percentage points of the vote. In presidential election years, gubernatorial candidates feel the impact of presidential coattails. ${ }^{30}$ For example, the estimates from specification 1 , version A, indicate that when a gubernatorial candidate's co-partisan presidential

\footnotetext{
${ }^{29}$ In all specifications, estimation of the model without an intercept (i.e., the regression line is forced through the origin) produces a coefficient of at least 0.90 for the normal vote. This suggests that a candidate for the incumbent party can expect to receive at least 90 per cent of the party's normal vote.

${ }^{30}$ Note, however, that the coefficients for the presidential coattails variables are statistically significant only in the two version A specifications. The version B specifications are estimated with fewer observations over a shorter time period. This is a time period in which most states ceased holding gubernatorial elections in 'on-presidential' years. Thus, we can infer that, as a class of events, gubernatorial elections are now less susceptible to presidential coattails because most are held in non-presidential election years. Furthermore, we explored the possibility that presidential popularity might impact gubernatorial elections more generally than merely through the vote for president. To do so, we entered in our model a variable that interacts yearly national presidential approval data with an inverse dummy variable that indicates whether or not the incumbent governor was a co-partisan of the president. In no specification did the coefficient for this interaction variable approach statistical significance, so we did not include it in the final model specifications. This result provided little surprise considering that, as discussed above, previous researchers have reached markedly different conclusions about whether presidential popularity impacts gubernatorial elections.
} 


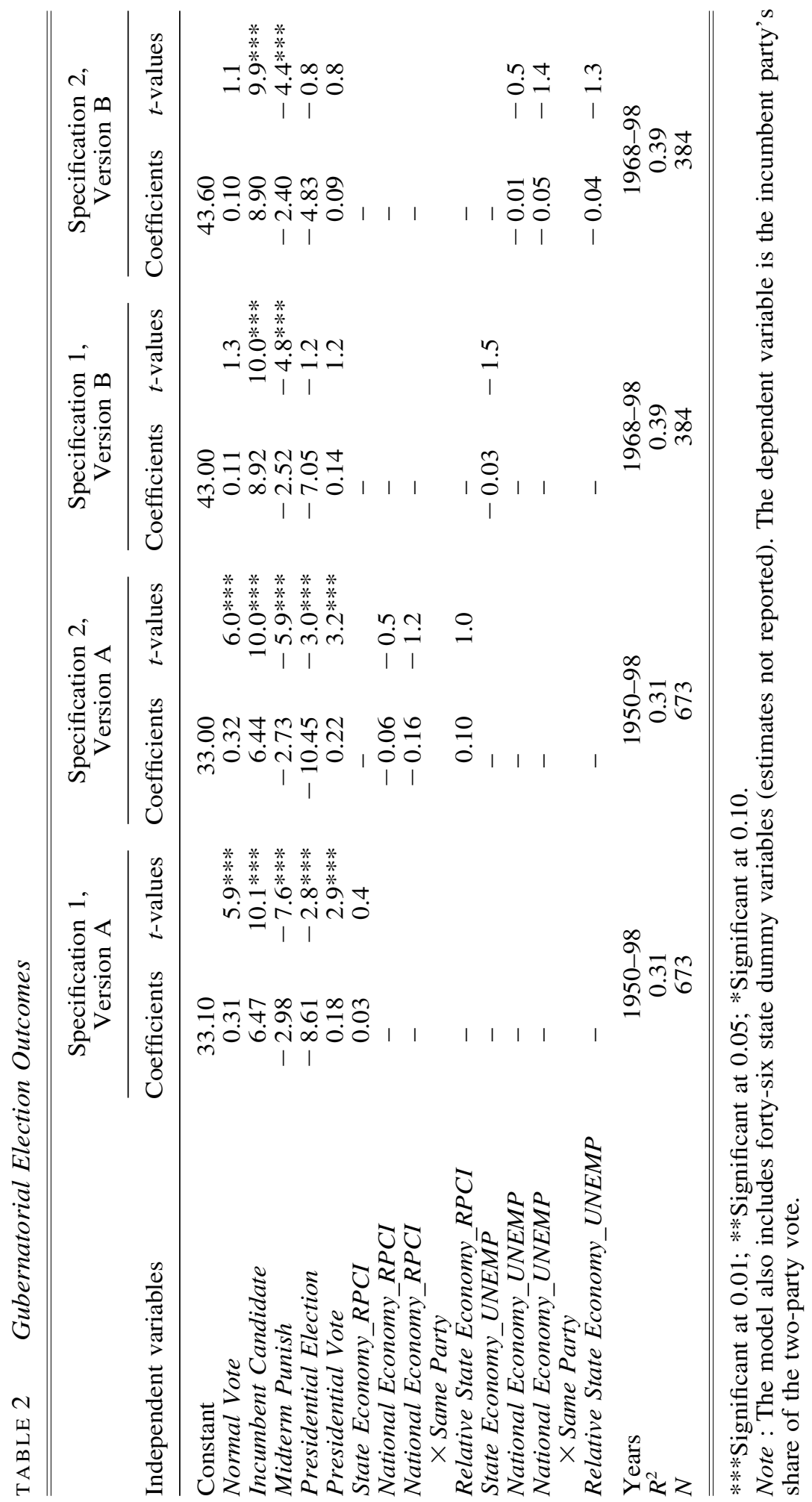


candidate wins a comfortable 55 per cent of the vote, the gubernatorial candidate can expect to gain more than 1 additional percentage point of the vote. ${ }^{31}$

According to the results in Table 2, state economic conditions have no great impact on gubernatorial elections. In specification 1 (both version A and B), the 'absolute' state economy does not register a statistically significant effect (at the 10 per cent level or lower) on incumbent vote share. In specification 2 (both version A and B), the estimate for state economic growth relative to national growth also fails to reach statistical significance. These results are consistent with Strategy 4, and with previous conclusions by Peltzman and others that voters do not appear to evaluate state officials with reference to absolute state economic conditions.

Furthermore, Table 2 casts doubt on the earlier conclusions that the president's management of the national economy 'dominates' gubernatorial elections (i.e., voters use Strategy 3). Voters in the US states do not appear to punish and reward governors for the president's economic performance. These results are at odds with those separately reported by Peltzman and Chubb. One possible explanation for this discrepancy is difference in the datasets: Peltzman and Chubb cover different time periods - 1949-84 and 1940-82, respectively - and analyse a more limited selection of gubernatorial elections (they both exclude odd-year elections, and Peltzman further omits all races in which the governor was elected to a two-year term).

\section{THE CONDITIONAL EFFECT OF ECONOMIC STRUCTURE}

To test our economic geography hypothesis, we return to the 'primary product' index displayed in Figure 1. For Rhode Island, for example, the primary product index was quite stable throughout the period under analysis, hovering around 1 per cent. For North Dakota, on the other hand, the index rises to over 50 per cent in some years and averages about 25 per cent for the entire period. Moreover, because of the volatility of weather and agricultural prices there are sizeable fluctuations in the index for states like North Dakota that have the highest reliance on primary products. For instance, during drought or flood years in North Dakota, the primary product index falls to around zero, making it indistinguishable from Rhode Island. Since the use of a primary product index that fluctuates from year-to-year can lead to occasionally perverse (and facially invalid) classifications, we use a five-year moving average.

We expect that the impact of state RPCI and unemployment on incumbent gubernatorial vote share will be conditioned by the state's economic structure. Specifically, we hypothesize that the strength of the connection between income or unemployment and incumbent support is highest in states that are least dependent on farming, agricultural services and mining. Therefore, we add to each specification of our basic model a multiplicative interaction term. ${ }^{32}$ In specification 3, version A, the absolute growth rate of

\footnotetext{
31 As discussed above, we estimate presidential coattails through the combined effect of the presidential election year dummy variable and the presidential vote share variable. In this hypothetical example where the gubernatorial candidate's presidential candidate receives 55 per cent of the vote, the calculation from specification 1 , version A of the impact on the gubernatorial candidate's vote is as follows: $(55 \times 0.18)+(1 \times-8.61)=1.29$.

${ }^{32}$ We also add to each specification a separate variable for the (un-interacted) primary product index. Although there is no reason to expect the primary product index to have a direct impact on incumbent vote share (i.e., there is no reason to expect voters in states where the primary product is low - or high - to be more or less likely to vote for an incumbent), it could nonetheless be correlated with incumbent vote share. That is to say, over time incumbent vote share and the primary product index might vary in unison for unknown or theoretically unclear
} 
state RPCI is interacted with the (moving average) primary product index, and in specification 4, version A, the growth in state RPCI relative to national RPCI is interacted with the (moving average) primary product index. Specification 3, version B, and specification 4 , version $\mathrm{B}$, do the same for unemployment.

The results are presented in Table 3. Again, there is little evidence that absolute state economic conditions play a role in gubernatorial elections. In Specification 3, version A, neither the state economy nor the interaction of the state economy and the primary product index are remotely close to statistical significance. However, in Specification 4, version $\mathrm{A}$, there is strong indication that relative state economic conditions impact election outcomes. The point estimates for the relative state economy and the interaction between the relative state economy and the primary product index are 0.63 and -0.02 respectively, and are statistically significant at the 5 per cent level, both alone and jointly. The magnitude of the relative state economy effect can be interpreted as follows. For every point increase in the percentage of the state economy attributable to primary products, the slope of the state economy on the incumbent vote decreases by 0.02 . The conditional effects of state economic structure on economic voting are displayed visually in Figure 2, which plots on the horizontal axis the primary product index through its sample range, and on the vertical axis the marginal effect on incumbent vote share of state RCPI growth 1 percentage point greater than national RCPI growth. The solid line is the conditional effect estimated in specification 4, version A, while the dotted lines depict lower and upper bounds of the 95 per cent confidence interval. As Figure 2 shows, relative state economic conditions have an effect on incumbent vote that is statistically distinguishable from zero (at the 5 per cent level) whenever a state's primary product index is approximately 19 or lower. Once 19 per cent of the state's economy is directly related to primary products - like Nebraska or Iowa in the 1960 s or North and South Dakota in the early $80 \mathrm{~s}$ - the conditional coefficient can no longer be distinguished from zero. Such reliance on primary products is, however, increasingly rare; the national average for the primary product index was around 20 per cent in the 1950s with several states well above 40 per cent, but by 1998 it was down to around 3 per cent with only a handful of states above 10 per cent.

The unemployment regressions tell a similar albeit slightly less striking story using a smaller sample. In specification 3, version $B$, the absolute state unemployment rate interacted with the primary product index does not have a strong effect on incumbent success. However, specification 4 , version B, reveals a statistically significant impact from the relative state unemployment rate and its interaction with the primary product index. Point estimates for these variables are -0.11 and 0.01 respectively, which again indicates that the impact of relative state economic conditions diminishes in states whose economies largely depend on primary products. Figure 3 plots out the conditional coefficients. ${ }^{33}$ Figure 3 shows that relative state economic conditions - when measured with unemployment data - have an effect on incumbent vote share that is statistically

(F'note continued)

reasons. We can control for this possibility - and ensure that our estimates of the interaction of the primary product index and state economic conditions are not contaminated by the possibility - by including an independent variable for the primary product index. However, because we do not expect the primary product index to have a direct impact on incumbent vote share, we also estimated all specifications reported in Table 3 without an independent variable for the primary product index. These results, which are available from the authors upon request, are nearly identical to those in Table 3 (i.e., including or excluding the independent variable for the primary product index does not have an appreciable impact on the estimates of the other variables).

33 Note that since the unemployment data are only available since 1968, the sample range displayed in Figure 3 for the primary product index has a different maximum from that seen in Figure 2. 


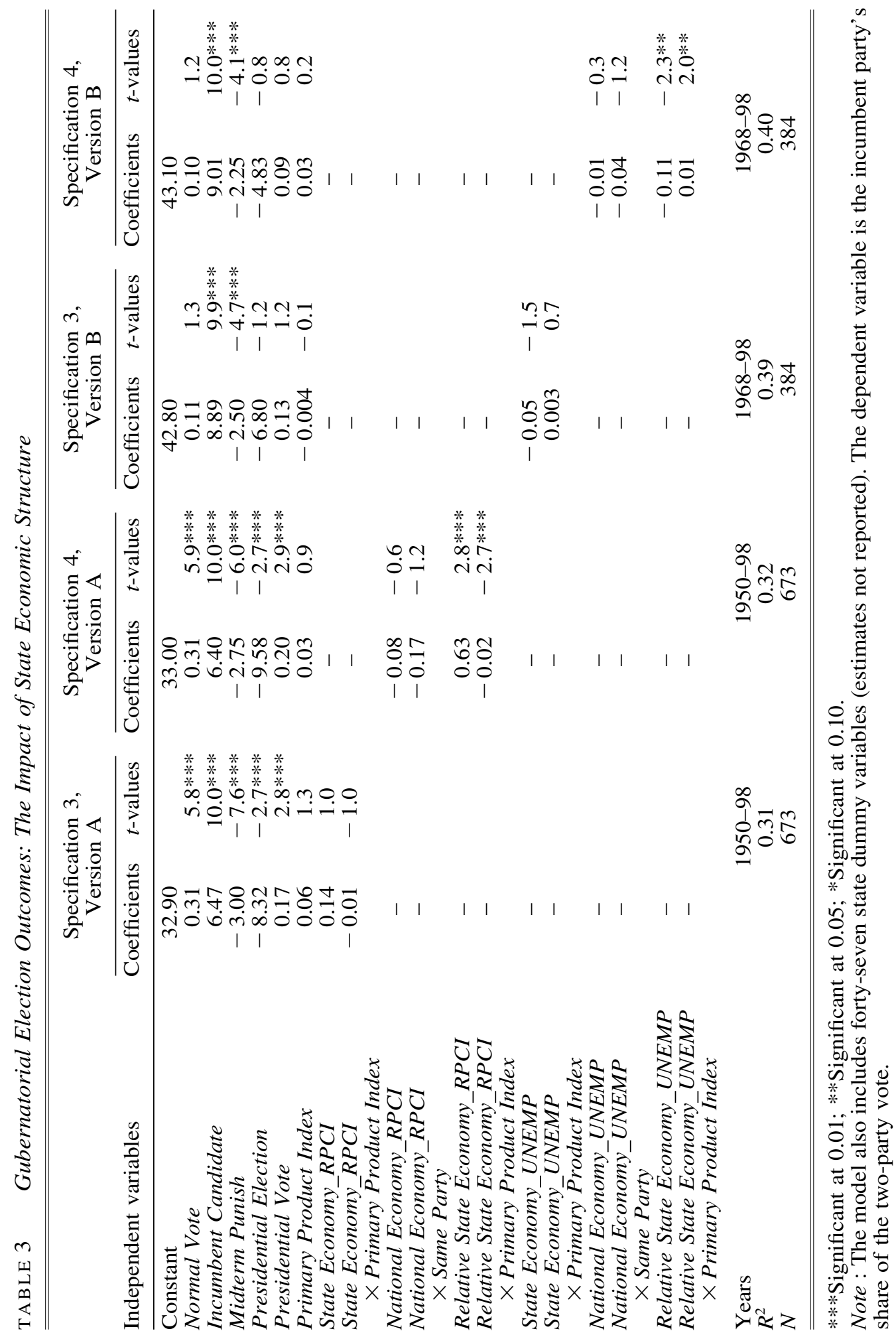




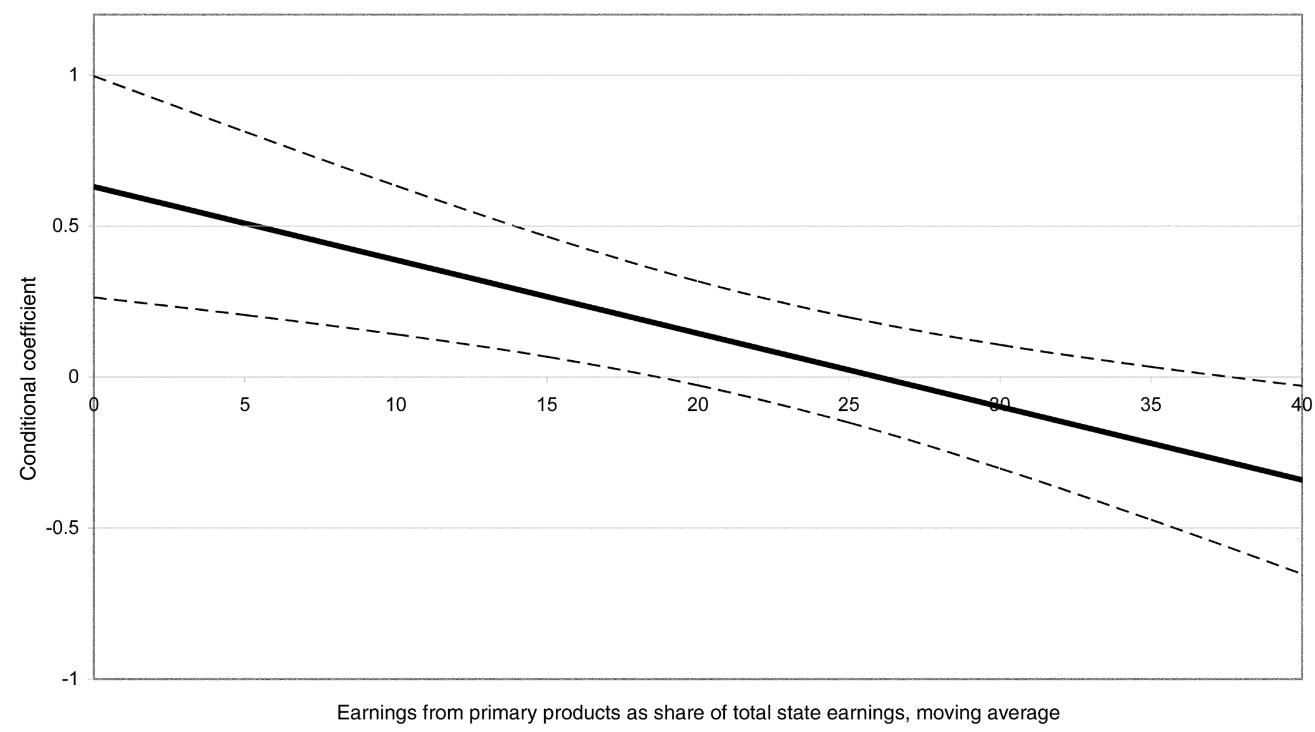

Fig. 2. Conditional effect of state per capita income growth (relative to national) on incumbent vote share

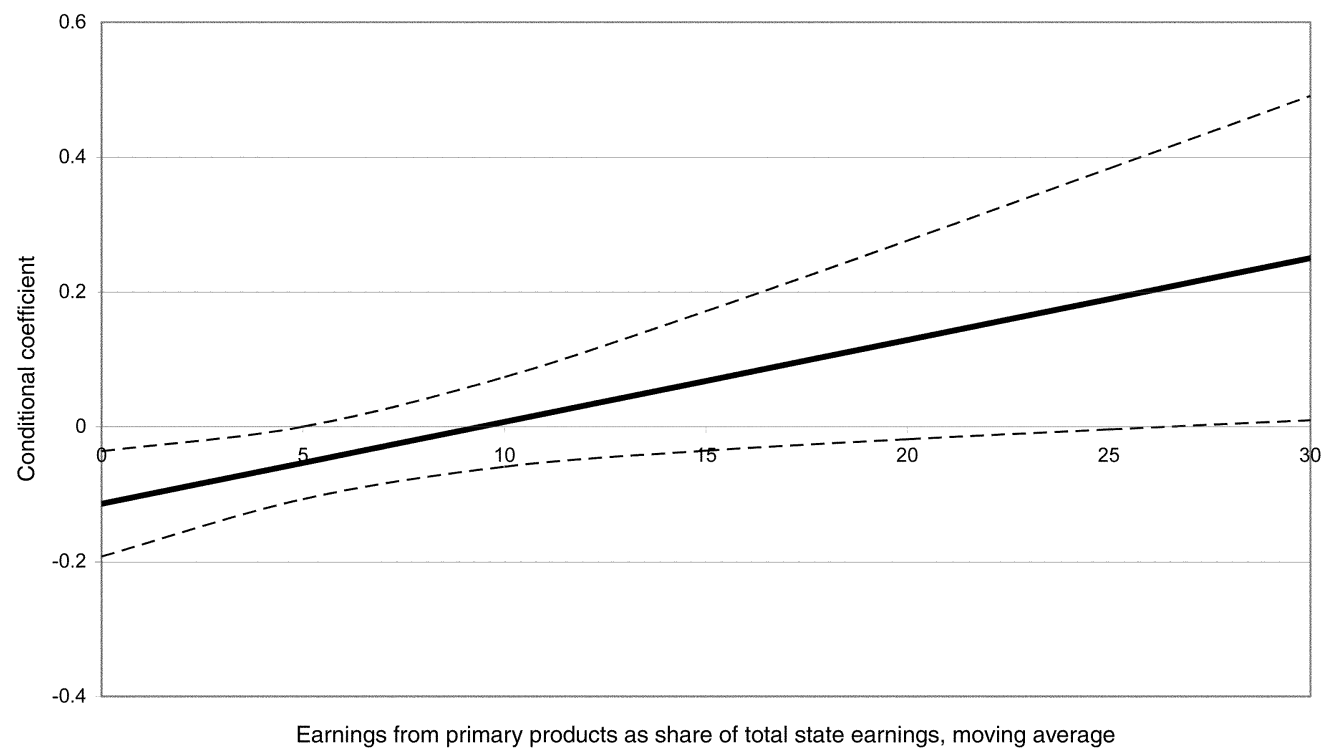

Fig. 3. Conditional effect of state unemployment growth (relative to national) on incumbent vote share

distinguishable from zero only in states with very little - in fact less than 5 per cent - of the economy devoted to primary products. By the 1980s this encompasses well over half of the states - every state in the northeast and along the pacific coast, most southern states, and even a good number of midwestern and western states. Thus, the unemployment specification mirrors the income growth specification: both suggest that as states have 
made the transition away from reliance on primary products, the connection between state economic conditions and gubernatorial elections has become more pronounced.

Although our results indicate that relative state economic conditions have a statistically significant impact on gubernatorial election outcomes, the question remains whether it is a substantively significant impact. To appreciate the substantive significance of our results, consider a hypothetical example, based on sample data, of the electoral impact in a state with 'very good' relative economic performance and very minimal reliance on primary products. Our sample range for relative state economic conditions as measured by RPCI growth is -15.84 to 34.30 , with a mean of 0.30 and standard deviation of 4.01 . We might, therefore, define a state as experiencing 'very good' economic performance if its relative RPCI growth rate is 4.31 or higher - i.e., one standard deviation or more above the mean. Such a state would, in other words, have had a RPCI growth rate more than 4 percentage points above the national RPCI growth rate. If that state's primary product index is very low - say, $1,{ }^{34}$ as is the case today in Rhode Island, among other states - then the overall impact on the incumbent party's share of the vote is calculated as follows: $(0.63 \times 4.31)+(-0.02 \times 4.31 \times 1)=2.63$. In other words, the incumbent gubernatorial party can expect an additional 2.63 per cent of the two-party vote in this scenario. Under the same hypothetical circumstances, the model specification that uses unemployment as the economic indicator (i.e., specification 4, version B) predicts that the incumbent gubernatorial party can expect an additional 1.33 per cent of the two-party vote. ${ }^{35}$ Such a marginal advantage of between 1 and 3 per cent of the vote is easily enough to swing a close election in favour of the incumbent.

\section{DISCUSSION AND CONCLUSION}

Our results indicate that the relationship between economics and elections at the state level is mediated by the state's economic structure. Specifically, signs of economic voting are most clearly discernible in states that rely least on farming and natural resources. This suggests that state-level economic voting only becomes common as states develop modern, diverse economies. Previous studies reporting no relationship between state economic conditions and gubernatorial election results were likely to have been driven in part by a handful of sparsely populated states. This finding should raise considerable doubt about previous notions that state-level economic prosperity does not impact state election outcomes. Like other recent studies focusing on partisanship, institutions and the clarity of responsibility, our study demonstrates that the economic-electoral connection is subtle and conditional. Economic voting is not a universal phenomenon. As such, studies of the economic-electoral connection - especially in multi-tiered governmental systems - need to take care in identifying the conditions under which voters might use economic and other types of information to evaluate the performance of incumbent politicians.

\footnotetext{
34 As mentioned above the sample range for the primary product index is 0.78 to 54.15 . The sample mean is 11.55 and the sample standard deviation is 10.65 . Thus, a primary product index 1 standard deviation below its mean is 0.9 , which is consistent with our intuitive sense that a primary product index of 1 or lower denotes very minimal reliance on primary products.

${ }^{35}$ The sample range for the relative percentage increase in unemployment rate is -34.69 to 60.19 , with mean of 0.52 and standard deviation of 13.86. For unemployment our definition of 'very good' economic performance is one standard deviation below the mean (because it is preferable, of course, that unemployment be lower rather than higher). Thus, the calculation for the hypothetical example is $(-0.11 \times-13.34)+(0.01 \times-13.34 \times 1)=1.33$.
} 
Voters who wish to assess the competence of incumbent politicians face a difficult task - namely, finding objective, trustworthy information about government performance. Although perhaps difficult to interpret, economic information may under some conditions be the best alternative. Under other conditions, however, economic information is likely to prove less helpful. A low growth rate vis-à-vis other states might convey useful information about government performance to voters in Connecticut or Michigan, but similar data are probably of less use to voters in North Dakota or Montana.

A goal for future research might be to examine other aspects of economic and political geography that would explain similar patterns. Since governors do not control monetary or trade policy, their efforts to claim credit for economic expansion focus primarily on attracting trade and investment. A key insight in the economic geography literature is that because of transport costs and agglomeration economies, their ability to do so depends heavily on the state's proximity to major markets and ports (though perhaps decreasingly so as transport costs fall). In other words, our 'primary product' index might be a function not only of abundant natural resources and fertile soil, but also transport costs and a state's distance from the major urban markets of North America and the world. Perhaps economic voting is only a reasonable strategy for voters in states that have geographic features allowing them to compete in the game of competitive federalism. Future work might examine such a hypothesis using data on inter-state and inter-national trade and investment patterns. It might also be useful to disaggregate further and use counties or metropolitan areas as units of analysis.

While suggesting that the link between economics and accountability might vary over time and space, the results presented in this article do not prove that governors are less accountable to the electorate in states dependent on primary products, or even that voters in such states ignore the economy when evaluating their leaders. Perhaps voters in such states have developed context-dependent strategies for evaluating incumbent performance. Future studies might focus on these states and examine whether state-level macroeconomic variables are indeed associated with incumbent success in models that control for factors like commodity prices, weather and crop yields. It would also be useful to examine the apportionment of credit and blame across levels of government for fluctuations in farm subsidies and price supports, given the importance of these in determining income levels in some regions.

Our results can also be interpreted in the light of ongoing debates about the naïveté or rationality of voters. We find little evidence that voters base their decisions on raw state-level macroeconomic aggregates. Rather, they appear to filter out the potential noise introduced by nation-wide shocks and federal policy by comparing state-level unemployment and income growth rates to the national average. ${ }^{36}$ More importantly, economic information is most tightly linked to incumbent success in the states where such information most plausibly contains useful performance signals

In addition to further study of economic geography and accountability in the United States, our approach also points the way towards an intriguing research agenda in comparative politics. First, future cross-national studies of economic voting might

\footnotetext{
36 Wolfers presents a similar finding, which he asserts is evidence that voters rationally collect and process information about the economy. He goes on to show, however, that voters nonetheless make systematic attribution errors, for instance when they improperly blame or reward incumbents in the aftermath of oil shocks (Justin Wolfers, 'Are Voters Rational? Evidence from Gubernatorial Elections' (Stanford Graduate School of Business Research Paper No. 1730, 2002)).
} 
take into account the structure of national economies. Secondly, studies of economic voting might shed light on vexing questions about the accountability of government to citizens, especially in federal and multi-tiered political systems. If voters use economic information to hold subnational officials accountable, they may do so either by implicitly - and exclusively - tying them to the performance of the national executive, as in Germany; or, as in the US manufacturing core, they may view subnational governments as relatively 'sovereign' and hold elected officials separately accountable for local outcomes. This article has introduced the possibility that voters develop different accountability strategies in different regions within the same country. Future research might attempt to establish the political, economic and fiscal conditions under which these strategies are compatible with voters' incentives and information. 
